\title{
4.4 Розбудова університетської системи академічної доброчесності як основи професійного розвитку в умовах цифровізації суспільства
}

У сучасних умовах цифровізації суспільства та інтеграції України до світового освітнього та Європейського дослідницького простору різнобічне дослідження ц̌ ефективне вирішення проблеми дотримання науковопедагогічними працівниками і здобувачами вищої освіти академічної доброчесності як основи професійного розвитку $\epsilon$ вельми актуальним. Важливість зумовлена тим, що питання правових, технологічних, етичних засад академічної доброчесності знайшли законодавче закріплення в низці чинних державних нормативно-правових документів в Україні й за кордоном i потребують консолідації зусиль академічної спільноти для широкого впровадження принципів академічної доброчесності у вітчизняний та міжнародний освітній простір. Крім того, актуальність дослідження полягає в нагальній необхідності розбудови у кожному закладі вищої освіти університетської системи академічної доброчесності як невід'ємної складової корпоративної культури і внутрішньої системи забезпечення якості освіти із метою систематичного залучення суб'єктів освітнього процесу (науковопедагогічних працівників, здобувачів вищої освіти, слухачів курсів підвищення кваліфікації) до неперервного професійного розвитку як конкурентоздатних фахівиів, основою якого є академічна доброчесність. Важливим у цьому контексті $\epsilon$ вдумливе вивчення, різнобічний порівняльний аналіз, чітке стратегічне i тактичне осмислення кращих практик побудови системи академічної доброчесності, запропонованих вітчизняними та зарубіжними вишами, із метою творчого застосування у конкретному закладі вищої освіти.

Теоретичним підгрунтям дослідження стали праці відомих науковців і практиків: 1) у сфері академічної доброчесності (Артюхов А., Буяк В., Гужва О., Гунчак В., Дегтярьова І., Лічман Т., Мельниченко А., Ніколаєв С., Пшенична Л., Рудик В., Сацик В., Семененко Л., Слободянюк О., Сорокіна Н., Сурай I., Хименко О., Христинченко Н., Чепіга М., Черенеко Н., Чумак О., Чуканова С., 
Фініков Т. та ін.); 2) у сфері професійного розвитку науково-педагогічних працівників, здобувачів вищої освіти, слухачів курсів підвищення кваліфікації (Кириченко М., Отич О., Сорочан Т. та ін.); 3) у сфері цифровізації науковоосвітньої діяльності (Биков В., Спірін О. та ін.); 4) у сфері дослідження досвіду зарубіжних країн у формуванні культури академічної доброчесності й запровадженні кращих практик у вітчизняну систему освіти (Батечко Н., Дурдас А., Лічман Т., Хмарський В. та ін.).

Мета дослідження - схарактеризувати процес розбудови університетської системи академічної доброчесності як основи професійного розвитку науковопедагогічних працівників та здобувачів вищої освіти Державного закладу вищої освіти «Університет менеджменту освіти».

Слід зазначити, що на сучасному етапі розвитку системи освіти науковопедагогічна спільнота постала перед низкою цивілізаційних викликів, передовсім, пов’язаних із глобалізацією, диджиталізацією та світовою пандемією COVID-19, що спричинили кардинальні зміни у всіх сферах життєдіяльності соціуму $[281,283]$. Наразі зростає кількість рейтингів і методів оцінювання конкурентоспроможності закладів вищої освіти, що змушує їх постійно дбати про престиж у суспільстві, невід'ємною складовою якого є професійний розвиток та дотримання суб'єктами освітнього процесу академічної доброчесності. На ці виклики Державний заклад вищуої освіти «Університет менеджменту освіти» реагує системно, комплексно та оперативно, адже від ефективності модернізації системи освіти в цілому, і вищої зокрема, залежить досягнення цілей сталого розвитку України, формування й збереження суспільних цінностей, забезпечення національної безпеки держави. У Стратегії розвитку Державного закладу вищої освіти «Університет менеджменту освіти» на період до 2024 року зазначено, що його перевагою $є$ належність до структури Національної академії педагогічних наук України, зорієнтованість на формування цілісної системи неперервної освіти і поступальне входження до європейського освітнього простору [287, с. 4]. 3 поміж стратегічних изілей розвитку ДЗВО «Університет менеджменту освіти» на 2020-2024 роки 
виокремлено: розвиток Університету як вільного освітнього, наукового, інноваційного простору, що об'єднує спільними цінностями і завданнями здобувачів освіти і персонал закладу; створення умов для навчання і розвитку здобувачів вищої освіти - особистостей зі сформованими компетентностями фахівця XXI століття з активною громадянською позицією, відповідальністю за свою долю i долю держави, конкурентоздатних на ринку праці; розвиток університету як центру дослідно-експериментальної роботи і експертної діяльності у системі післядипломної освіти; формування моделі інноваційного університету системи вищої освіти, спроможного успішно конкурувати на ринку європейських освітніх послуг; входження ДЗВО «УМО» до ТОП-100 кращих університетів України за показниками освітньої і наукової діяльності [287, с. 5]. Пріоритетним завданням ДЗВО «УМО», як закладу вищої освіти і освіти дорослих є формування інноваційного середовища підготовки, професійного й особистісного розвитку фахівців у системі формальної, неформальної й інформальної освіти завдяки модернізації форм і змісту їхнього навчальнометодичного і наукового супроводу, активного використання можливостей відкритої освіти, системи мотивації особистісного і професійного розвитку [287, c. 5]. ДЗВО «УМО» покликаний обгрунтувати i розкрити можливості професійного розвитку кожного науково-педагогічного працівника для оволодіння новими технологіями і методиками, що сприятиме якості освітнього процесу, усвідомленому вибору кожним студентом і слухачем своєї освітньої траєкторії, здатності приймати зважені рішення, активній участі у конструюванні та коригуванні освітнього контенту [287, с. 6].

Із метою розбудови у Державному закладі вищзої освіти «Університет менеджменту освіти» системи академічної доброчесності, забезпечення дотримання принципів академічної доброчесності й етики академічних взаємовідносин та сприяння професійному розвитку науково-педагогічних працівників адміністрація університету та фахівці відділу наукової роботи здійснюють науково-методичний супровід із таких актуальних проблем:

1) ознайомлення з теорією і практикою академічної доброчесності в галузі 
освіти і науки [279, 280, 282, 284, 285];

2) вивчення міжнародних та державних нормативно-правових документів iз проблеми академічної доброчесності в галузі освіти і науки; опрацювання структурними підрозділами університету вимог Міністерства освіти і науки України та Національного агентства із забезпечення якості вищої освіти до наукових, науково-педагогічних, педагогічних працівників, здобувачів вищої освіти із проблеми академічної доброчесності;

3) відпрацювання категоріального апарату 3 проблеми академічної доброчесності в галузі освіти і науки та проявів її у вищій школі (академічна доброчесність, принципи академічної доброчесності, етика академічних взаємовідносин, соціальна відповідальність за результати наукової та освітньої діяльності тощо);

4) вивчення кращих практик розбудови системи академічної доброчесності та здійснення порівняльного аналізу, узагальнення, систематизації передового вітчизняного й зарубіжного досвіду вирішення проблеми академічної доброчесності в галузі освіти і науки;

5) опрацювання вимог НАПН України та Державних стандартів до наукової, виробничо-практичної, навчальної, довідкової продукції, готової до впровадження (оприлюднення, розповсюдження, використання) на теренах України й зарубіжжя;

6) ознайомлення науково-педагогічних працівників із ефективними формами оприлюднення і розповсюдження наукової, виробничо-практичної, навчальної, довідкової продукції, готової до впровадження, серед представників науково-педагогічної спільноти України й зарубіжжя;

7) аналіз ефективності індивідуальної і колективної участі науково-педагогічних працівників у наукових і освітніх заходах різного формату та статусу, зокрема, із проблематики академічної доброчесності;

8) урахування в календарі проведення подій університету періодичності проведення заходів із академічної доброчесності з метою включення їх до плану роботи закладу вищої освіти, планомірної участі у цих заходах структурних 
підрозділів, педагогічних і науково-педагогічних працівників закладу відповідно до планів роботи кафедр та індивідуальних планів роботи;

9) наукове рецензування, експертиза, моніторинг якості конкурсних робіт, наукових заходів (наприклад, Конкурси Національної академії педагогічних наук України, науково-методичний супровід підготовки і подання творчими колективами кафедр ДЗВО «Університет менеджменту освіти» пакетів документів на науково-дослідну тему для участі науково-педагогічних працівників у Конкурсному відборі для виконання наукових досліджень із проблем розвитку освіти, що потребують невідкладного розгляду (http://naps.gov.ua/ua/press/announcements/2180/);

10) специфіка роботи структурних підрозділів та уповноважених комісій, що забезпечують впровадження принципів академічної доброчесності в освітню, наукову, методичну, організаційну діяльність університету й виконують наглядову і контролюючу функції.

Слід зазначити, що принципи академічної доброчесності в Державному закладі вищої освіти «Університет менеджменту освіти» закладено в основу організаційної культури університету загалом та кожного структурного підрозділу зокрема. Значна увага адміністрації та фахівців відділу наукової роботи приділяється доведенню цінності, політики та процедур академічної доброчесності до науково-педагогічних, наукових, педагогічних працівників, здобувачів вищої освіти та слухачів курсів підвищення кваліфікації.

Однією з ключових складових внутрішньої системи забезпечення якості в Державному закладі вищої освіти «Університет менеджменту освіти» $\epsilon$ університетська система забезпечення академічної доброчесності, розбудова якої ефективно здійснюється згідно з чинними законодавчими нормативноправовими документами з урахуванням вимог Міністерства освіти і науки України [285], рекомендацій Національного агентства із забезпечення якості вищої освіти [284].

Слід наголосити, що на сучасному етапі розвитку освіти істотну допомогу адміністрації та науково-педагогічним працівникам закладів вищої освіти 
України надало Національне агентство із забезпечення якості вищої освіти, що рекомендувало здійснити розбудову Університетської системи забезпечення принципів академічної доброчесності та етики академічних взаємовідносин [284, c. $4-5]$.

Метою університетської системи забезпечення академічної доброчесності є визначення та утвердження основних пріоритетних принципів і цінностей внутрішнього забезпечення якості вищої освіти, дотримання яких представниками академічної спільноти Університету $є$ необхідною умовою створення сприятливого освітнього середовища, обміну знаннями та їх примноження, упровадження інновацій, інтелектуального розвитку здобувачів вищої освіти, слухачів курсів підвищення кваліфікації, замовників освітніх послуг і науково-педагогічних, педагогічних працівників.

Завдання університетської системи забезпечення академічної доброчесності: 1) підтримка особливих взаємовідносин на засадах людино(студенто- викладацько-)центризму, відкритості, чесності, порядності, взаємної довіри, справедливості, рівної відповідальності, взаємоповаги, толерантності та ін.); 2) запобігання будь-яких проявів недоброчесної поведінки, дискримінації та порушення академічної доброчесності; 3) утвердження чесності й етичних цінностей в освітньому процесі й науковій діяльності університету; 4) формування високої академічної культури, носіями якої повинні бути науково-педагогічні, педагогічні працівники та здобувачі вищої освіти, слухачі курсів підвищення кваліфікації, замовники освітніх послуг; 5) запобігання порушенням академічної доброчесності тощо.

Система включає такі елементи: 1) політику, стандарти та нормативну базу університету 3 питання академічної доброчесності; 2) інституційне забезпечення (структурні підрозділи (посадові особи), що опікуються питаннями академічної доброчесності та чіткий розподіл відповідних функцій i повноважень між структурними підрозділами (посадовими особами) університету; 3) інформаційно-технологічні засоби університету 3 питання академічної доброчесності. 
Розглянемо складові елементи системи забезпечення академічної доброчесності в освітній і науковій діяльності Державного закладу вищої освіти «Університет менеджменту освіти», які логічно пов’язані між собою та об'єднані в такі блоки (малюнок 1):

I. Політику, стандарти та нормативну базу (внутрішню, зовнішню) Державного закладу вищої освіти «Університет менеджменту освіти» 3 академічної доброчесності, яка на системному рівні описує механізми впровадження принципів академічної доброчесності в науковий та освітній процеси, заходи із забезпечення процесу дотримання принципів академічної доброчесності, процедури попередження та боротьби з порушеннями принципів академічної доброчесності. Нормативні питання академічної доброчесності регламентовано у системі внутрішніх документів Державного закладу вищої освіти «Університет менеджменту освіти» [286], а саме: 1) Стратегії розвитку Університету менеджменту освіти на період до 2024 р.; 2) Положенні про академічну доброчесність у Державному закладі вищої освіти «Університет менеджменту освіти»; 3) Наказі «Про затвердження порядку перевірки текстів на академічний плагіат у Державному закладі вищої освіти "Університет менеджменту освіти"»; 4) Положенні про комісію з питань етики та академічної доброчесності; 5) Наказі «Про затвердження складу комісії з питань етики та академічної доброчесності у Державному закладі вищої освіти "Університет менеджменту освіти"»; 6) Положенні про систему внутрішнього забезпечення якості освітньої діяльності та якості вищої освіти у Державному закладі вищої освіти «Університет менеджменту освіти»; 7) Положенні про моніторинг якості освітньої діяльності та якості вищої освіти здобувачів першого (бакалаврського), другого магістерського), третього (наукового) рівнів, слухачів підвищення кваліфікації ДЗВО «Університет менеджменту освіти»; 8) Етичному кодексі університетської спільноти. 
Система забезпечення академічної доброчесності в освітній і науковій діяльності

Державного закладу вищої освіти «Університет менеджменту освіти»

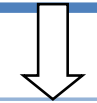

I БЛОК - Політика, стандарти, нормативна база Державного закладу вищої освіти «Університет менеджменту освіти» $з$ академічної доброчесності

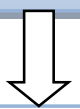

II БЛОК - Відповідальні особи у структурних підрозділах Державного закладу вищої освіти «Університет менеджменту освіти» та Комісія з питань етики та академічної доброчесності

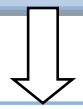

III БЛОК - Інформаційна база Державного закладу вищої освіти «Університет менеджменту освіти» з академічної доброчесності

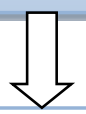

IV БЛОК - Інструменти впровадження принципів академічної доброчесності у освітню і наукову діяльність Державного закладу вищої освіти «Університет менеджменту освіти»

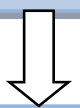

V БЛОК - Інструменти контролю дотримання академічної доброчесності у освітній і науковій діяльності Державного закладу вищої освіти «Університет менеджменту освіти»

Малюнок 1. Складові системи забезпечення академічної доброчесності в освітній і науковій діяльності ДЗВО «Університет менеджменту освіти» (підготовлено авторами на основі рекомендацій НАЗЯВО України [284, с. 4-5])

II. Відповідальних осіб у структурних підрозділах Державного закладу вищої освіти «Університет менеджменту освіти» та уповноважену Комісію 3 питань етики та академічної доброчесності, яка забезпечує популяризацію принципів академічної доброчесності, їх упровадження в освітньо-наукову діяльність університету, а також виконує наглядову та контролюючу функції.

III. Інформаційну базу Державного закладу вищої освіти «Університет 
менеджменту освіти» $з$ академічної доброчесності, за допомогою якої здійснюється популяризація принципів академічної доброчесності та підвищення рівня обізнаності всіх учасників освітньо-наукової діяльності в університеті у питаннях академічної доброчесності та основними складовими якої є:

а) рубрики сайту університету із висвітленням актуальних питань академічної доброчесності;

б) інформаційні та методичні матеріали, присвячені інформаційній грамотності та попередженню плагіату;

в) інформаційні матеріали щодо корпоративної культури на робочому місці та переваг чесного навчання, наприклад, Етичний кодекс університетської спільноти.

г) матеріали, присвячені популяризації принципів академічної доброчесності серед осіб, що здобувають вищу освіту (інфографіка, роздаткові матеріали).

IV. Інструменти впровадження принциипів академічної доброчесності $у$ освітню і наукову діяльність Державного закладу вищої освіти «Університет менеджменту освіти», які виконують просвітницьку функцію та за допомогою яких стає можливим попередження випадків порушення принципів академічної доброчесності, зокрема:

а) інформаційно-консультативний супровід фрахівизів університету (педагогічних, науково-педагогічних, наукових працівників та інших категорій співробітників) та здобувачів вищої освіти через створення відповідних ресурсів на сайті, діяльність із промоції принципів академічної доброчесності;

б) інтернет-посилання для викладачів $і$ студентів на масові відкриті онлайн-курси за тематикою академічної доброчесності та основ інформаційної грамотності;

в) реалізація у освітніх програмах здобувачів вищьої освіти та програмах підвищення кваліфікащії науково-педагогічних i педагогічних працівників окремих актуальних питань академічної доброчесності. 
$V$. Інструменти контролю додержання академічної доброчесності $y$ освітній і науковій діяльності Державного закладу вищої освіти «Університет менеджменту освіти», які передбачають:

a) проведення анкетування учасників наукового та освітнього процесів на предмет порушень академічної доброчесності;

б) обов'язкову перевірку наукових, навчально-методичних, кваліфікаційних та навчальних робіт на наявність ознак академічного плагіату відповідно до створеної нормативної бази.

Таким чином, університетська система забезпечення академічної доброчесності спрямована на:

1. Дотримання моральних і правових норм поведінки всіма учасниками освітнього проиесу Державного закладу вищої освіти «Університет менеджменту освіти», зокрема вимог до професійної (наукової, освітньої, методичної, інноваційної, творчої) діяльності науково-педагогічних і педагогічних працівників, реалізацію їхньої місії з обміну знаннями та їх примноження в суспільстві, яке навчається, державної політики у сфері вищої і професійної (професійно-технічної) освіти.

2. Реалізаиію освітньої і науково-дослідної діяльності здобувачів вищої освіти в академічному середовищі при здійсненні наукової, освітньої, інноваційної і творчої діяльності для забезпечення високого рівня довіри до результатів освітнього процесу, наукових і творчих досягнень.

3. Інструменталізацію академічної доброчесності як цінності, необхідної академічному середовищу, переведення академічної доброчесності в набір повсякденних професійних дій і сталих освітніх практик.

Важливим кроком для утвердження високих етичних норм і доброчесності в академічній спільноті університету є ознайомлення із Положенням про академічну доброчесність та підписання науково-педагогічними, педагогічними працівниками та здобувачами вищої освіти Декларачіï про академічну доброчесність, яке здійснюється в такі терміни: 1) науково-педагогічні, 
педагогічні працівники - під час прийому на роботу; 2) здобувачі вищої освіти - впродовж місяця з дня зарахування до університету [286].

Положення про академічну доброчесність у Державному закладі вищої освіти «Університет менеджменту освіти» регулює якість і дотримання етичних вимог науково-педагогічними, педагогічними працівниками, здобувачами вищої освіти, слухачами курсів підвищення кваліфікації, замовниками освітніх послуг в основних сферах діяльності Університету: 1) освітній (освітня діяльність здобувачів вищої освіти, слухачів курсів підвищення кваліфікації, викладацька діяльність науково-педагогічних працівників), 2) науковій (написання випускних, магістерських, бакалаврських робіт, дослідницьких проєктів, наукова діяльність, публікація результатів наукових досліджень тощо), 3) методичній (науково-методичний супровід професійного розвитку фахівців в умовах формальної, неформальної, інформальної освіти), 4) у міжособистісному спілкуванні [286]. У Положенні про академічну доброчесність у ДЗВО «УМО» визначено: 1) сутність поняття «академічна доброчесність»; 2) основні види порушень академічної доброчесності; 3) компетентності із дотримання принципів академічної доброчесності в університеті; 4) засоби запобігання академічному плагіату та його виявлення; 5) повноваження Комісії 3 питань етики й академічної доброчесності; 6) форми відповідальності за порушення академічної доброчесності науково-педагогічними, педагогічними працівниками, здобувачами вищої освіти, слухачами курсів підвищення кваліфікації; 7) права осіб, стосовно яких порушено питання про притягнення до відповідальності за порушення академічної доброчесності [286].

Слід наголосити, що у межах розбудови університетської системи академічної доброчесності (представленої на Міжнародній виставці «Освіта та кар’єра - 2020» (21 листопада 2020 р.) здійснено розробку і розпочато реалізацію освітнього проєкта «Академічна доброчесність у науковому та освітньому nросторі: духовність, якість, сталий розвиток» для суб'єктів освітнього процесу Державного закладу вищої освіти «Університет менеджменту освіти». 
Автор-розробник проєкта: Острянська О. А., доцент відділу наукової роботи Державного закладу вищої освіти "Університет менеджменту освіти" Національної академії педагогічних наук України, кандидат педагогічних наук, доцент. Базова кафедра від університету для реалізації проєкта: кафедра педагогіки, адміністрування і спеціальної освіти Навчально-наукового інституту менеджменту та психології ДЗВО «Університет менеджменту освіти» за очільництва Сіданіч І. Л., завідувача кафедри, доктора педагогічних наук, доцента.

Мета освітнього проєкта «Академічна доброчесність у науковому та освітньому просторі: духовність, якість, сталий розвиток»: 1) навчальна ознайомити суб'єктів освітнього процесу із поняттям «академічна доброчесність» як основоположним принципом якісної освітньої і науководослідної діяльності; із чинною законодавчою базою та нормативно-правовим забезпеченням Міністерства освіти і науки України, Національного агентства із забезпечення якості вищої освіти, ДЗВО «Університет менеджменту освіти» 3 питань дотримання академічної доброчесності як складової академічної культури у закладах вищої освіти України; видами порушень академічної доброчесності та академічною відповідальністю за ці порушення; основними функціями антиплагіатних систем; вибраними освітніми практиками й комплексом дій щодо забезпечення академічної доброчесності при підготовці наукових публікацій і кваліфікаційних робіт; формувати у суб'єктів освітнього процесу академічну доброчесність як складову академічної культури особистості, наскрізні академічні компетентності та соціальну відповідальність як складові конкурентоздатності особистості; 2) розвивальна - розвивати у суб'єктів освітнього процесу дивергентне мислення, пізнавальний інтерес, мовлення, мотивацію до дотримання принципів академічної доброчесності у процесі реалізації освітньої та науково-дослідної діяльності, оприлюднення і розповсюдження іiі результатів; 3) виховна - виховувати у суб'єктів освітнього процесу доброчесність як стрижневу якість особистості; повагу до праці педагогічних і науково-педагогічних працівників; шанобливість до академічної 
спільноти та організаційної культури ДВО «Університету менеджменту освіти»; прагнення дотримуватися академічної доброчесності та культивувати іiї серед представників студентської та науково-педагогічної спільноти.

У межах заходів, спрямованих на реалізацію названого проєкта, підготовлено методичний посібник «Академічна доброчесність у сучасному науковому та освітньому просторі» (упорядники: О. А. Острянська, І. Л. Сіданіч. Київ: ДЗВО «УМО», 2021). Крім того, розроблено документацію для забезпечення успішної діяльності студентського наукового гуртка та наукової лабораторї «Академічна синергія», що функціонують при кафедрі педагогіки, адміністрування і спеціальної освіти Навчально-наукового інституту менеджменту та психології ДЗВО «Університет менеджменту освіти» (Бібліографічні дані: Організація діяльності студентського наукового гуртка у закладі вищої освіти: Методичний посібник / упорядники: О. А. Острянська, І. Л. Сіданіч. Київ: ДЗВО «УМО», 2021).

Також у межах реалізації освітнього проєкта «Академічна доброчесність у науковому та освітньому просторі: духовність, якість, сталий розвиток» здійснено розробку навчально-методичного комплексу з навчальної дисципліни для магістрантів «Академічна доброчесність та основи академічного письма» (автор-розробник - Острянська О. А., кандидат педагогічних наук, доцент), що включає такі складові: 1) навчальну програму дисципліни; 2) робочу програму навчальної дисципліни; 3) силабус із навчальної дисципліни; 4) критерії оцінювання результатів навчання; 5) тексти лекцій із навчальної дисципліни (конспекти лекцій із методичними вказівками щодо проведення); 6) розробки та методичні рекомендації до проведення практичних занять; 7) навчальнометодичне та організаційне забезпечення самостійної роботи магістрантів із навчальної дисципліни; 8) навчально-методичне та організаційне забезпечення виконання магістрантами індивідуальних навчально-дослідних завдань із навчальної дисципліни; 9) методичне забезпечення поточного та підсумкового контролю навчальних досягнень магістрантів із навчальної дисципліни, зокрема: а) завдання і тести для поточного (модульного) контролю знань, умінь і навичок 
магістрантів; б) питання і завдання до семестрового контролю 3 навчальної дисципліни; в) критерії оцінювання навчальних досягнень магістрантів; г) комплексну контрольну роботу 3 навчальної дисципліни; 10) навчальнометодичне забезпечення практичної підготовки магістрантів (завдання для роботи під час проходження практики); 11) навчально-методичне забезпечення виконання магістрантами кваліфікаційних робіт.

Активно здійснюється розробка науково-методичного та інформаційного забезпечення освітнього процесу з навчальної дисцииліни «Академічна доброчесність та основи академічного письма» у вигляді окремих видань (монографії, навчально-методичного посібника, хрестоматії, глосарію (понятійно-термінологічного словника), методичних рекомендацій із навчальної дисципліни).

Яскравим прикладом організащуї масових науково-методичних заходів для студентів, спрямованих на формування академічної доброчесності, $\epsilon$ розроблений захід «Естафета академічної доброчесності: від конкурентоспроможного випускника до першокурсника», який дозволяє об’єднати у спільній справі дотримання академічної доброчесності першокурсників університету зі студентами середніх i старших курсів бакалаврату та магістратури, а також спонукає старшокурсників при символічному передаванні «естафети академічної доброчесності» до подання першокурсникам власного прикладу дотримання принципів академічної доброчесності як невід'ємної складової етичних норм діяльності членів університетської спільноти. Цей захід розроблено у творчій співпраці структурних підрозділів університету: науково-педагогічних працівників відділу наукової роботи, кафедри педагогіки, адміністрування і спеціальної освіти. Важливою для студентів є систематична плідна співпраця із Радою молодих учених Національної академї педагогічних наук Украӥни, зокрема із проблематики академічної доброчесності. У межах функціонування Літньої школи для молодих дослідників розроблено тренінг для магістрантів $i$ аспірантів «Академічна доброчесність у науці та освіті: успішні сходинки для 
освітянина, науковця, управлінця». Слід підкреслити, що дуже важливим у розбудові якісної університетської системи академічної доброчесності $\epsilon$ застосування принципу перспективності й наступності у систематичному дотриманні академічної доброчесності від першокурсника до конкурентоспроможного випускника Державного закладу вищої освіти «Університет менеджменту освіти», а тому інформацію про політику академічної доброчесності закладено в силабуси та робочі програми навчальних дисциплін як стрижневі компоненти змісту навчання майбутніх фахівців конкретних освітньо-професійних (наприклад, «Педагогіка вищої школи», «Християнська педагогіка») ma освітньо-наукових програм (наприклад, «Спеціальна освіта (за нозологіями)»). У межах співпраці наукової бібліотеки 3 іншими структурними підрозділами ДЗВО «Університет менеджменту освіти» проводиться копітка систематична робота по наповненню Репозитарію електронних ресурсів Університету. Цікавими й змістовними для здобувачів вищої освіти є тематичні виставки літератури «Академічна доброчесність: віртуальний путівник», різноманітні заходи до Тижня академічної доброчесності. Також створено електронні опитувальники для науковопедагогічних працуівників $і$ здобувачів вищзої освіти з проблематики академічної доброчесності; науково-методичну документацію для провадження групової та індивідуальної проєктної діяльності з означеної проблеми. Слід наголосити, що розроблення навчально-методичних матеріалів із академічної доброчесності здійснюється на компетентнісній основі та спрямовується на забезпечення принципу студентоцентрованості.

Перспективними є: 1) розробка Програми підвищення кваліфікащіï $з$ академічної доброчесності та основ академічного письма для керівників, науковцүів, освітян; 2) організація секиійних засідань із проблематики академічної доброчесності, наприклад, на традиційних науково-практичних конференціях здобувачів вищої освіти і молодих учених; 3) публікація наукових статей у збірнику матеріалів «Наука $і$ молодь: пріоритетні напрями 
глобалізаційних змін» Навчально-наукового інституту менеджменту та психології ДЗВО «Університет менеджменту освіти» та ін.

Здійснюється перевірка на академічну доброчесність наукових результатів діяльності науково-педагогічних працівників, отриманих у процесі виконання науково-дослідних тем, зокрема результатів наукових досліджень та науково-технічних (експериментальних) розробок, які можуть бути представлені: в офіційній продукиії (стандарти, інструкції, нормативні, нормативно-інструктивні видання); в науковій продукиії (монографії, препринти, збірники наукових праць); y виробничо-практичній продукцї (практичні посібники, методичні посібники; методичні рекомендації, практичні порадники); y навчальній продукції (навчальні програми, підручники, навчальні посібники (навчально-методичні, навчальні наочні посібники, хрестоматії, практикуми, робочі зошити); у засобах навчання (навчально-наочні ігрові посібники; атласи; навчальні карти; відео- та аудіовізуальні засоби навчання; електронні засоби навчального призначення; електронні засоби загального призначення); 8 довідковій продукції (енциклопедії (енциклопедичні словники); мовні, лінгвістичні словники; довідники, каталоги).

Із метою успішного впровадження наукових здобутків ДЗВО «Університет менеджменту освіти» важливим $є$ оприлюднення i розповсюдження їх на масових міжнародних наукових заходах, які мають високий статус та популярність серед представників науково-педагогічної спільноти. Саме тому, Національна академія педагогічних наук України, Державний заклад вищої освіти «Університет менеджменту освіти» та Громадська спілка «Всеукраїнська академія інноваційного розвитку освіти» виступили організаторами й активними учасниками вебінару «Академічна доброчесність у сучасному науковоосвітньому просторі: правовий, технологічний та морально-етичний аспекти» (21 листопада 2020 р.) у межах Міжнародної виставки «Освіта та кар’єра - 2020». Метою вебінару $\epsilon$ об’єднання зусиль науковців, практиків, державних і громадських діячів у вирішенні актуальних проблем імплементації принципів академічної доброчесності у сучасний науково-освітній простір, висвітлення 
вітчизняного і європейського досвіду вирішення правового, технологічного й морально-етичного аспектів академічної доброчесності у підготовці та професійному розвитку студентів і науково-педагогічних працівників в умовах диджиталізації суспільства. Цільовою аудиторією вебінару стали науковопедагогічні, педагогічні працівники, керівники закладів загальної середньої, вищої освіти, докторанти, аспіранти, здобувачі вищої освіти. Змістовна програма вебінару передбачала різнобічне обговорення актуальної проблеми академічної доброчесності, яка комплексно висвітлювалася висококваліфікованими, досвідченими спікерами вебінару. Значний інтерес учасників викликало обговорення таких проблем: 1) правові аспекти академічної доброчесності; 2) технологічні аспекти академічної доброчесності $y$ сучасному науково-освітньому просторі; 3)морально-етичні аспекти академічної доброчесності в умовах диджсталізаиї суспільства; 4) зарубіжний $i$ вітчизняний досвід упровадження принципів академічної доброчесності $y$ сучасний науково-освітній простір. Наукова платформа вебінару, який тривав понад чотири години поспіль, стала унікальним місцем для творчої співпраці, плідного науково-освітнього й соціального партнерства представників різних галузей, обговорення й вирішення актуальних проблем академічної доброчесності, розгляду шляхів налагодження й зміцнення дієвої співпраці між науковцями і практиками. Актуальні ц̆ змістовні доповіді спікерів, супроводжувані цікавими інформаційно насиченими мультимедійними презентаціями, сприяли висвітленню кращого вітчизняного і європейського досвіду вирішення правового, технологічного й морально-етичного аспектів академічної доброчесності, який учасники вебінару (науково-педагогічні, педагогічні працівники, керівники закладів загальної середньої, вищої освіти, докторанти, аспіранти, здобувачі вищої освіти) мали змогу сприйняти, обговорити, вдумливо осмислити і творчо застосувати у процесі професійної підготовки, особистісного і професійного розвитку й саморозвитку суб'єктів освітнього процесу в умовах диджиталізації суспільства.

Таким чином, ефективність процесу розбудови системи академічної 
доброчесності як основи професійного розвитку науково-педагогічних працівників і здобувачів вищої освіти в умовах цифровізації суспільства залежить від урахування прогресивного вітчизняного й зарубіжного досвіду та злагодженої індивідуальної й колективної (командної) роботи адміністрації університету, науково-педагогічних працівників кафедр із науковими підрозділами закладу вищої освіти.

Якісна розбудова системи академічної доброчесності за визначеними складовими допомагає науково-педагогічним працівникам університету в повній мірі вирішувати складні стратегічні й тактичні завдання представлення результатів наукової та освітньої діяльності на теренах вітчизняного й міжнародного науково-освітнього простору, систематичного впровадження результатів наукових досліджень, розширення доступу до інновацій, технологій і спільних проектів, зміцнення взаємовигідних ділових міжрегіональних і міжнародних зв'язків, отримання фахового визнання творчих здобутків науковопедагогічною спільнотою та стейкхолдерами.

Перспективи подальших наукових досліджень убачаємо в глибокому науково-методологічному осмисленні прогресивного вітчизняного й зарубіжного досвіду з формування основ академічної доброчесності у суб'єктів освітнього процесу, науковому обгрунтуванні та експериментальній перевірці технології формування академічної доброчесності як основи професійного розвитку науково-педагогічних працівників у процесі інтернаціоналізації вищої освіти. 